\title{
Parenting style in building learning motivation in children: A case study in migrant
}

\section{workers' families in Indonesia}

\author{
Ulvi Oktaliana ${ }^{{ }^{*}}$ \\ Maria Veronika Roesminingsih ${ }^{2}$ \\ Suhanadji ${ }^{3}$ \\ ${ }^{1,2,3}$ Post Graduate Program, Surabaya State University, Surabaya, Indonesia
}

\begin{abstract}
This study aims to describe the role of parenting to students whose parents work as immigrants with substance in the form of student opinions, as well as to describe the learning motivation of students whose parents work as migrant workers with several approaches related to learning motivation. The study used a qualitative approach that took data based on the results of interviews and direct observations as a data collection instrument and then carried out descriptive analysis. The sample of this study was conducted on students at MI Al-Khoiriyah and SDN Langenharjo 2 schools whose parents worked as immigrants.

The results showed that students realized that with the parenting pattern of parents who worked as immigrants this situation was only temporary, their parents worked for money to be able to meet their needs at home and students' educational needs. However, in general, students feel sad when their parents are away from them for a long time so that students experience a lack of direct parental love. Therefore, in general, students whose parents work as immigrants do not show good or high learning motivation. This can be seen from the incompleteness of eight indicators of student learning motivation at school. Suggestions for further research in the future are also discussed.
\end{abstract}

\section{KEYWORDS}

Learning motivation; migrant workers; parenting

Received: 27 July 2021

Accepted: 3 August 2021 Published: 9 August 2021

\section{Introduction}

Education for human life is an absolute need that must be fulfilled by humans throughout their lives. Without education, it is impossible for a group of people to live and develop in line with what they want. On the other hand, education is an important element in the development of a nation and has an important role in improving the quality of human resources. Therefore, various efforts must be made to improve the quality of education, especially the quality of elementary school education (SD).

The main purpose of education in elementary schools is to form the basis of students' personalities as complete human beings and have character according to the level of self-development of elementary school students. In accordance with the Regulation of the Republik Indonesia Nomor 20 Tahun 2003 concerning the National Education System "Education is a conscious and planned effort to create a learning atmosphere and learning process so that students actively develop their potential to have religious spiritual strength, self-control, personality, intelligence, noble character, and skills needed by themselves, society, nation and state". Efforts to improve the quality of human resources are one of the emphases of educational goals, as stated in the Law of the Republik Indonesia Nomor 20 Tahun 2003 concerning the objectives of National Education which states that "National Education aims to develop the potential of students to become human beings who believe and are pious to God, have character, are healthy, knowledgeable, capable, creative, independent, and become a democratic and responsible citizen.

Family is a fundamental factor that contributes to a child's development. For a child, the family is the first social and educational environment. Therefore, parents must be aware of educational strategies for their children, 
for example through behavioral models offered by family members and through the psychosocial climate that exists in the family. In addition to teachers, the role of parents in education is needed as a material for the development of a better child education. Parents are figures who have an important role in physical, emotional-social, psychological development and intelligence development in receiving learning in schools that have been given by teachers at school.

The 2013 curriculum shows that the role of parents in education is very necessary, in this curriculum parents have their own position and part in guiding students to study at home, so that in the 2013 curriculum teaching materials there are guidelines for parents to guide students in the learning process at home. The research related to this discussion is a research conducted by Necsoi, Daniela Veronica, (2013) with the title "The Relationship Between Parental Style and Educational Outcomes of Childern in Primary School in Romania". Beyond parenting style, the home and school partnership is a strong predictor of school achievement (Dauber \& Epstein, 1993). In other words, schools should involve parents in programs that teach them how to be supporting, affective with their children and how to manage child supervision. These programs should teach parents how create a learning environment that would increase the academic achievement of their children.

The results of the research above reveal that schools must involve parents in children's teaching programs, how to be affective supporters of children and how to manage child supervision. These programs aim to teach parents how to create a good learning environment to improve their children's achievement. The greater the role of the family in children's learning, the more likely children are to get a quality education (Morrison, 2013). Ideally, parenting in the family is carried out by both parents. In this case, it means that father and mother are working together to help each other in providing care, motivation and education for their children.

With the existence of families who have to work as migrants for their daily needs, the condition of the family is in an incomplete position because one of their parents or even both works outside the island or even abroad. Candirejo Tegowangi, Plemahan District, Kediri Regency is one of the villages where most of the population works as migrant workers abroad. Their desire to become migrant workers is to get a decent job and earn a high income. SDN Langenharjo and MI Al-Khoiriyah are schools located in one sub-district, namely plemahan sub-district. SDN Langenharjo 2 is located in Langenharjo village, Plemahan sub-district where the majority of the students have different backgrounds. We need to get information by conducting a study entitled "Parenting patterns in building learning motivation in children" (A case study in migrant workers' families in MI Al-Khoiriyah and SDN Langenharjo 2 Kediri).

\section{Literature review \\ Parenting}

Parenting is closely related to the growth and development of children, parenting refers to the way parents treat, educate, guide, and protect their children during the maturation process, including efforts to instill the norms expected by society in general. (Narsidah, et al, 2014). Parenting patterns in parental care for children refer to an implementation that is very important for children's growth and development, because parental care is the main factor in determining the potential character of a child. Kazak, A. E. (2006), Therefore the right start to make the most important part of family education in children can be through behavioral models offered by family members and through the psychosocial climate that exists in the family.

Family education strategies greatly determine the personality development and educational achievement of children. Families, especially parents, are role models for children and adolescents. Parents should have a good personality regarding attitudes, habits, behavior, and ways of life. Families of Indonesian Migrant Workers have the biggest challenge in the process of child care because the father or mother and even both have to be separated from their children for a long period of time.

Narsidah, et al (2014) Many explain the factors that can affect the success of child migrant workers to adapt to the environment. First, the family environment where the child is raised. If children are educated by their parents in an authoritarian and strict manner, then as adults, children often feel resentful and find it difficult to interact with authoritarian figures they meet in society. It is different from children who are raised indifferently by their parents, often they show attitudes and feelings of indifference to others.

\section{Forms of parenting}

Baumrind (as cited in Masud, 2016) classifies parenting styles as behaviors, values and standards that are transmitted to children, and these behaviors, values and standards are expected to be adopted by children. Narsidah (2014) states that there are four forms of parenting styles, namely: authoritarian parenting, democratic parenting, neglecting or indifferent parenting, and permissive or indulgent parenting. 


\section{Influential factors of parenting patterns}

According to Hurlock (as cited in Wulandari, 2019) parenting patterns are influenced by several factors, including the following:

a. Parent's personality

Everyone is different in their level of energy, patience, intelligence, attitude and maturity.

b. Beliefs

The beliefs that parents have about parenting will affect the value of parenting and will affect their behavior in raising their children.

c. Similarities to parenting accepted by parents

If parents feel that their parents used to be successful in applying their parenting style to their children well, then they will use similar techniques in parenting.

\section{Motivations to learn}

Motivation in terms of learning includes two things: (1) knowing what to learn, and (2) understanding why it is worth learning. Based on these two elements of motivation, it can be used as a good starting point for learning. If there is no motivation and motivational elements above, the teaching and learning process activities will be difficult to succeed. The motivation given to students will provide an impetus or feedback to these students to learn and of course will have high motivation in learning so that it will have an impact on the activities and learning achievements of these students. Student learning activities will look conducive if students have high learning motivation, so that student activities focus on the learning process and thus student learning achievement becomes more optimal.

\section{Methods}

The research used is a qualitative research by adopting a qualitative descriptive approach used to analyze the data. Phenomenology is the study of knowledge that comes from awareness or how to understand an object or event by experiencing it consciously (Littlejohn, 2003). According to Alfred Schutz (in Hasbiansyah, 2008), the process of meaning begins with the sensing process, a continuous process of experience. This flow of sensory experience is, at first, meaningless. There is an individual meaning and there is also a collective meaning about a phenomenon. Our consciousness processes sensory data. For Schutz, human actions always have meaning. However, there is no real meaning in life. Then the implementation is done with Phenomenology in the situation experienced so that there are no limits in interpreting or understanding the phenomenon under study and researchers can analyze the data obtained.

The phenomenological approach tries to let reality reveal itself naturally. Through "giving questions", research subjects tell all kinds of dimensions of their experience related to a phenomenon or event (Hasbiansyah, 2008). The purpose of phenomenological research is to seek or find meaning from the essential or fundamental to life experiences experienced and to try to understand the meaning of events and their relationship to people in certain situations.

Sources of data taken in this study are data related to parenting and learning motivation of students whose parents work as immigrants. Data related to student learning motivation is based on observations made using observation sheets and interviews. The study was conducted at the MI Al-Khioriyah school and SDN Langenharjo 2 Kediri with a sample of 32 students in grades I-VI, whose parents worked as immigrants.

\section{Data collection}

Sugiyono (2018) states that in qualitative research, data collection is carried out in natural settings (natural conditions), primary data sources, and many techniques include participant observation, in-depth interviews and documentation.

\section{a. Observation}

The type of observation used in this study is passive participation observation. Researchers come to the place of the activities of people who are observed but are not involved in these activities (Sugiyono, 2018). The focus of the study on learning motivation is that the researcher observes student activity in the classroom which includes student participation in the form of student questions and answers with the teacher, student behavior in the classroom, and student responses in the classroom during the learning process. 
b. Interview

This interview activity was conducted by researchers focusing on students' learning motivation, activity and behavior of students in the classroom and their responses during learning activities. Before conducting the interview, the researcher made a list of questions related to the problems to be asked in order to get complete and in-depth answers. The more and more information obtained, the easier it is for researchers to explain or find problems experienced by informants or respondents.

c. Documentation

This documentation technique uses photos and notes. This documentation study is a complement to see students' learning motivation based on midterm exam and final exam scores as well as to analyze students' learning activities whether they are in accordance with the criteria for mastery learning.

\section{Data analysis}

Researchers used the Credibility of trust, Transferability (involvement), Depenability (dependence), and Confirmability (certainty) tests. Data analysis in this study was carried out at the time of data collection, the data analysis used was the Miles and Huberman model. According to Miles and Huberman (1984) stated that three activities were carried out in conducting data analysis, namely: data reduction, data presentation, and conclusion drawing/verification. The components of Miles and Huberman's data analysis are described as follows:

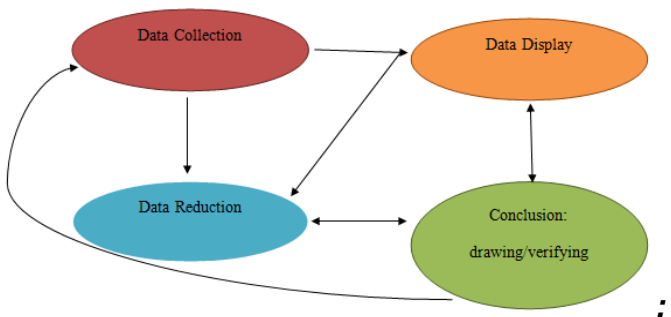

Figure 1. Components in the interactive model of data analysis (Miles and Huberman as cited in Sugiyono, 2018)

\section{Results}

This section presents research data using a qualitative descriptive approach about the role of the relationship between parenting and children's motivation in migrant worker families. This research was conducted on students of MI Al-Khoiriyah and SDN Langenharjo 2. with several statements answered by students whose parents work as immigrants..

Table 1. Statements of students whose parents work as immigrant workers

\begin{tabular}{cl}
\hline NO & \multicolumn{1}{c}{ STATEMENT } \\
\hline 1 & Children's opinion on parenting patterns of parents who work as migrant workers \\
\hline $\mathbf{2}$ & Learning motivation of students whose parents work as migrant workers \\
\hline $\mathbf{3}$ & Persevere in the task \\
\hline $\mathbf{4}$ & Resilience in the face of adversity \\
\hline $\mathbf{5}$ & Shows interest in various issues \\
\hline $\mathbf{6}$ & Prefer to work independently \\
\hline $\mathbf{8}$ & Get bored quickly with routine tasks \\
\hline $\mathbf{9}$ & Can defend his opinion and not easily give up his belief \\
\hline
\end{tabular}

Based on Table 1, the results of data collection were carried out and then analyzed into one and the resulting data were then explained as follows:

\section{Research results on students}

Children's opinion on parenting patterns of parents who work as migrant workers

Based on the results of the interview, students felt a feeling that was still in a normal state when their parents were not at home with them every day because he worked, of course students understood that. However, the 
student experienced sadness and cried when his parents came home for a short time and then said goodbye to return to work abroad. As time goes by, students begin to feel that it is normal when their parents can fulfill their wishes by frequently asking how they are and also sending money for them. The student also realized that his parents' job was to earn a living to meet their daily needs. For this reason, students sometimes feel lonely because there are no parents who accompany and guide them at home as a place to tell stories. They feel very homesick for the presence of their parents at home, this is expressed in tears when talking about parents. Students prefer to play with their friends rather than stay silent, this causes students to experience a decrease in self-confidence because there is nothing to motivate them. When asked further, they really want their parents to always be at home to accompany them to play, study, make breakfast for him, and he will also be happy if his mother always gathers with his family at home. For them, parents are good, loving, patient and caring people. attention to their children.

\section{Learning motivation of students whose parents work as migrant workers}

The forms of student learning motivation can be seen through aspects from outside and from within students. The motivation that exists in everyone has the following characteristics: (1) Perseverance in dealing with tasks (can work continuously for a long time, never stops before completion), (2) Tenacious in the face of difficulties (not easily give up), (3) Shows interest in various problems, (4) Prefers to work alone, (5) Gets bored quickly on routine tasks, (6) Can defend his opinion, (7) It is not easy to let go of things he believes in, (8) Happy to find and solve problems.

Based on interviews, those whose parents left working as immigrants lacked perseverance in learning, tended to be lazy to do assignments from school, especially tasks that were very difficult for them. These students have various reasons why they never do online schoolwork, because they do not get the perfect attention, direction, advice and guidance from their families. When there is a school assignment, the response is so bad that they often don't turn in the assignment. their parents never know that their children never turn in their schoolwork because they never tell their parents about the school activities, besides that their parents are too busy with their work so there is no time for him to pay attention to their child's educational progress.

However, there are also students who are very active in the learning process at school. When students get school assignments, they always work hard, this can be seen when they work on questions independently in class without seeing the answers from their friends and students always ask for a little extra time if they haven't finished their assignments, students actively ask if there is material they don't understand .

\section{Persevere in the task}

Based on field notes and interviews, students who were abandoned by their parents as immigrant workers lacked perseverance in learning, students tended to be lazy to repeat the material that had been taught and even lazy. do the tasks from school, let alone the tasks that are very difficult for him. He often shows an attitude of giving up easily when he gets difficult questions from his teacher. Students prefer to play with their cellphones and play at their friends' houses to reduce their boredom at home.

\section{Resilience in the face of adversity}

The results of field notes and interviews, it is known that the tenacious attitude of students when facing difficulties is still not visible, this can be seen in the attitudes shown by students, namely when learning takes place students are less enthusiastic and passive. in responding to assignments from the teacher, they are not immediately responded to or done, they prefer to postpone their work by choosing to go to play with their friends until the afternoon. Her focus is not on school and teacher assignments but on things she enjoys such as playing on her cell phone and cycling with her friends. So that students who are abandoned by their parents who work as immigrant workers can pursue learning like their other friends, the teacher should provide special guidance to these students so that their enthusiasm for learning grows. There are also students who have a tenacious attitude when faced with difficulties. This can be seen when they are actively involved in the learning process. They immediately do the assignments given by the teacher and try to find answers to these questions independently or from other learning resource books.

\section{Shows interest in various issues}

The results of observations and interviews with research subjects can be seen that students whose parents work as immigrant workers tend to show a passive attitude during the learning process. This can be seen when students do not respond to the teacher through question and answer activities. If students have difficulty, they do not directly ask the teacher but just stay silent and answer the question without thinking about whether the answer he wrote is right or wrong. Meanwhile, students who actively participate in learning activities tend to be responsive when doing activities asking teachers and peers. 


\section{Prefer to work independently}

The results of field notes and interviews that have been conducted show that students whose parents leave one of them working as immigrant workers still show an attitude of not being able to work independently towards school assignments given by the teacher. These students also tend to be less responsible for assignments. This can be seen when getting assignments from the teacher, students always see when the schedule for assignments is collected, if the time to collect is still long then he will not immediately do the assignments, students prefer to postpone the assigned tasks. Students also often ask their friends for help to answer questions and often they study in groups so that they can find out the answers to these questions even though the task is an independent task, not a group task. Not infrequently he still asks for guidance from his homeroom teacher during face-to-face learning in class. The attitude of this initiative has also been slightly visible, this is shown by trying to find answers to these questions through the internet. The attitude form of students who prefer to work independently in class or at home when studying online is that students always try to do assignments independently without asking for help, students use other learning resources either through the internet, children's study magazines, other textbooks they have if the answer is yes. assignments have not been found, and students like to try new challenging things, for example working on other questions that have not been given by the teacher.

\section{Get bored quickly with routine tasks}

Based on the results of field notes and interviews, it can be concluded that in terms of getting bored quickly with the routine tasks of students whose parents work as immigrant workers abroad are still not visible, this is indicated by this behavior of students who do not like to be given too much work. Students feel more relaxed with this online learning, the attitude of students whose parents work as immigrant workers feel happy when school is off because assignments are not directly collected on the day the teacher gives assignments. Students reason that they are tired when given too many assignments, often delay or even finish assignments quickly so they can play with their friends. They prefer activities that do not require heavy thought processes such as playing online games, playing with friends around the house, and helping parents with household chores such as sweeping and washing dishes.

\section{Can defend his opinion and not easily give up his belief}

Based on the results of field notes and interviews, students who are able to defend their opinions tend to always strengthen their opinions if they are true and correct. It was explained that students who were abandoned by their parents working as immigrant workers abroad showed a lack of confidence, and were passive in the learning process. Students feel embarrassed when the teacher provides space for the question and answer process, students from TKI families only answer questions when appointed by the teacher, although sometimes it is difficult to express their opinions. They also often do not focus and pay less attention to the teacher when delivering lessons so that the student cannot understand what material has been explained and when given an assignment he is confused to ask his friends. However, some students whose parents work as immigrant workers show active, creative and confident attitudes and behaviors when participating in the learning process. These students are students who are able to defend their opinions and do not easily let go of what they believe can be seen from their behavior, namely by thinking critically about the various problems they face, besides that they are also actively involved in asking the teacher and giving their opinions or arguments and are not afraid to respond to problems. .

\section{Find and solve problems}

Based on the results of observations and interviews, students who were abandoned by their parents working as migrant workers tend to be less able to solve problems in the form of problems they face. The lack of critical and innovative thinking in working on the problems and assignments he receives will lead to lazy attitudes and behavior in learning, especially in doing assignments. This lazy attitude triggers the emergence of easy actions to despair and only rely on answers or help from friends.

Lack of innovative and creative thinking in working on problems and assignments leads to lazy attitudes and behavior in learning, especially in doing assignments. This lazy attitude triggers desperate actions and only relies on answers or help from friends. The students who were left by their parents to work as migrant workers worked on the questions independently when no one was asked for help, but they lacked effort to find the right answers to the questions. However, there are some students whose families apply good parenting, are disciplined, care about children's needs, and always provide assistance in student learning and always provide direction when children feel unable to act. 


\section{Discussion \\ Children's opinions about parenting patterns of parents who work as immigrant workers}

Based on the results of the research, it can be said that the optimal form of attention, encouragement, support and care from the closest family of students will be able to have a positive impact on students' self and mental development. With the presence of a person who cares for him so much. Giving more attention to students to the maximum then students will also be able to develop themselves to the fullest. Children whose parents work as migrant workers will certainly need more attention and support so that students are able to adapt and undergo the process of growing and developing well. However, if the student does not get all that from the closest party, then the student will try to seek attention from others.

\section{Learning motivation of students whose parents work as immigrant workers}

Students at MI Al-Khoiriyah and SDN Langenharjo 2 stated that most of them were very passive when participating in learning and almost never submitted the assignments given by the teacher, when asked they always reasoned with various reasons which the teacher said was a defense. Based on interviews with their class teachers, they stated that students whose parents left working as immigrant workers often did not do their schoolwork, some even never turned in their assignments, this was due to a lack of encouragement and support from the caregivers and family. They don't care about their children's educational needs, so they leave their students alone even though they don't do the homework from their homeroom teacher.

Overall, the situation of those who are left behind by their parents who work as immigrant workers in it must live and be cared for by one of their parents, some are cared for by their grandparents. With these conditions and if the treatment is wrong, it will result in them not having a high enthusiasm for learning both when studying at home and at school. Based on the research, all students whose parents work as immigrant workers lack the motivation to learn because they do not fulfill the eight aspects of learning motivation.

\section{Conclusion}

Based on the results of the study, several conclusions can be drawn as follows, the opinion of the children of MI Al-Khoiriyah and SDN Langenharjo 2 towards their parents who work as immigrant workers. Most of the students tend to feel sad when their parents are away from them for a long time due to work to meet the needs of students and families. some students who feel used to having been abandoned by their mother or father figure working abroad, they revealed that since childhood their parents had left them to work as immigrant workers and rarely returned home. But they all realized that the situation they were in was only temporary, their parents worked to earn money to support themselves and their families at home. For learning motivation, there are still many students of MI Al-Khoiriyah and SDN Langenharjo 2 whose parents work as immigrant workers who have not shown good or high learning motivation. This can be seen from the unfulfilled eight indicators of learning motivation. This is necessary to cultivate good relations in the child's family.

In order to increase student interest in learning with existing parenting patterns, it is necessary to have special assistance from students, considering that students are still young but at that age they do not receive direct love from their parents. The role of the teacher is very necessary to understand the actual situation of students.

But certainly in increasing student learning motivation also has limitations. So there needs to be a more approach for teachers to students who are at the SD/MI level whose parents work as immigrant workers by providing motivation and also giving more attention to students who do not feel deep loneliness.

\section{Acknowledgements}

Thanks to all parties involved in this research including teachers and students at MI Al-Khoiriyah and SDN Langenharjo 2 so that this research was carried out well.

\section{Funding}

This research received no specific grant from any funding agency in the public, commercial, or not-forprofit sectors.

\section{References}

Depdiknas .(2003). Undang-undang RI No.20 Tahun 2003 tentang Sistem Pendidikan Nasional.

Epstein, J.L., \& Dauber, S. L. (1991). School program and teacher practices of parental involvement in inner-city elementary and middle schools. Elementary School Journal, 91(3), 289-305. 
Hasbiansyah, O. (2008). Pendekatan fenomenologi: Pengantar praktik penelitian dalam ilmu sosial dan komunikasi. Mediator.Vol 9(1).

Kazak, A. E. (2006). pediatric psychosocial preventative health model (PPPHM): Research, practice, and collaboration in pediatric family systems medicine. Families, Systems \& Health, 24(4), 381-395.

Littlejohn. (2003). Theoris of human communication $7^{\text {h }}$ Edition Bolment. USA: Thomson Learning Academic Reurce Center.

Masud, Hamid., Muhammad, S.A., Farzand, A.J, \& Ahmad, Jamil. (2016). Relationship between Parenting Styles And Academic Performance Of Adolescents : Mediating Role Of Self-Efficacy. Asia Pacific Educ. 17:121-131.

Miles, M.B \& Huberman A.M. (1984). Analisis data kualitatif. Terjemahan oleh Tjetjep Rohendi Rohidi. (1992). Jakarta: Universitas Indonesia.

Morissan. (2013). Teori komunikasi : individu hingga massa. Jakarta: Kencana.

Narsidah, Eri Wahyuningsih, Rr Setyawati \& Mahmudah. (2014). buku pedoman pengasuhan anak BMI/TKI berbasis komunitas. Banyumas: Paguyuban Peduli Buruh Migran dan Perempuan "SERUNI".

Nescoi, D. V., Porumbu, D., Beldianu, I. F. (2013). The relationship between parental style and educational outcomes of children on primary school in romania. Journal of Procedia-Social and Behavioral Scienes, 82, 203-208.

Rahardjo, Susilo. (2011). Metodologi penelitian kualitatif. Bandung: PT. Remaja Rosdakarya.

Sugiyono. (2018). Metode penelitian kuantitatif, kualitataif, dan R\&D. Bandung: Alfabeta.

Wulandari, Ika Tri. (2019). Pola asuh orang tua dalam mengembangkan kemandirian anak kelompok b di RA perwanida kadipaten Kecamatan Andong Kabupaten Boyolali Tahun Pelajaran 2018/2019. Skripsi. Salatiga: Institut Agama Islam Negeri Salatiga. 